\title{
Application of GIS in Electricity Distribution: A Case Study of part of Ashamu Layout Kosobo, Oyo East Local Government Area, Oyo State Nigeria
}

\author{
Oseni A. E. ${ }^{1, *}$ and Durowoju A.S. ${ }^{1}$ \\ ${ }^{1}$ Department of Surveying and Geoinformatics, Bells University of Technology, Ota, Ogun State, Nigeria \\ Corresponding Author: *ayo_oseni@yahoo.com
}

https://doi.org/10.36263/nijest.2020.02.0106

\begin{abstract}
Due to the natural limitations faced by the old system of keeping, planning and managing the distribution of electricity, a computerized system is developed for Power Holding Company of Nigeria (PHCN), on Ashamu Layout of Kosobo Area, Oyo State, Nigeria. Data was acquired using south total station (NTS) and the data was downloaded using NTS.comp and project boundary was plotted with AutoCAD civil 3D, Im Ikonos resolution satellite imagery was downloaded and georeferenced with Arcgis10.1. Spatial features such as roads and buildings were vectorized. Electricity distribution and management was designed and created using relational database management system (rdbms) approach. The raster image was added as layer to ArcGIS 10.1 environments for geo-referencing and vectorization. The roads, buildings, electric poles were vectorized and a south total station was used to acquire co-ordinates of the electric poles and transformers to their position on the imagery, creating spatial database for the study area. The developed system was tested by carrying out spatial analysis and spatial search using ArcGIS 10.1. The results obtained were displayed in graphics and tables. It was established from the result that Geographic Information System (GIS) has the capacity as an effective tool for management of electricity distribution system.
\end{abstract}

Keywords: Electricity Distribution, GIS, Database, Management, Imagery

\subsection{Introduction}

Utility can be described as the facility that provides a collective aide to individual or organization. This refers to facilities such as roads, schools, hospitals, water, and electricity etc. GIS is a system that brings together various components that simplifies the task involved in the energy industry and utility industry. For proper management and maintenance of the electrical utility network, the Utility Information System which deals with management, planning, maintenance and mapping of utilities such as electricity, water etc. needs to be integrated. This is necessary for efficient distribution and maintenance of utilities.

Electrical Utility Network is the common term in the case of electrical transmission network, concerned in GIS environment. The network gets started from the source and ends with sink. The source is the generation point of electricity and the sink is the end point may be an industry/ a small house where the energy is best utilized. This electric utility network is an energy process flow in which it begins with the source, distributed through grid and transmitted to the ends by using transformers and gets connected by cables for its energy transfer. The role of GIS is to spatially map the entities and make the whole process in real time (ESRI, 2010).

Electricity is one of the most important and basic needs of today's community. Electricity is an aspect of the utility sector that is very essential to the smooth and meaningful development of the economy of our country. The projected growth of the Nigeria economy will be largely dependent on the performance of the power sector and ability to fulfill the growing demands of power supply. 
In the late falls of 2001; the Federal Government of Nigeria (FGN), worked very hard to see to the realization of steady power supply by the end of 2001 in the country. This was made known by the President when he gave an ultimatum to the then National Electric Power Authority (NEPA), which is later named as Power Holding Company of Nigeria (PHCN) and now known as Electricity Distribution Company (EDC), to stabilize power supply to the nation by 31st December 2001 . Obviously, NEPA raised electricity output from as low as 1,600 megawatts to 4,000 megawatts and over one billion dollars spent in order to meet up with the mandate (This Day Newspaper, 2002). The Nigerian Electricity Supply Industry (NESI) was unbundled into eighteen companies comprising 6 generating companies (GENCOs), 1 transmission company (TRANSYSCO) and 11 distribution companies (DISCOs). The bill that brought about the transformation of the Power Holding Company of Nigeria $(\mathrm{PHCN})$ from vertically integrated utility to these unbundled companies was signed into law in 2005. It was christened the Electric Power Sector Reform (EPSR) Act 2005. The reason was the unbundling was to improve electrical distribution due to poor management of the electrical utility system.

In order to efficiently and effectively manage and plan electricity distribution system in Nigeria, Geographic Information System (GIS) needs to be fully employed. As Geographic Information System is a decision-making tool for capturing, storing processing, manipulating, analyzing and displaying geographically referenced data; the potentials and challenges of using the GIS technique in utility mapping in a developing country as Nigeria, Adekunle (1995).

The problem associated with management and planning of distribution of electricity cannot be overemphasized. To achieve this, Utility Information System (UIS) need to be adopted. Utility Information deals with administration, planning, maintenance and mapping of infrastructure such as electricity, water, telephone etc. Ajibade (2002) defined utility management as an area of application which involves the provision, monitoring, protecting, management and maintenance of socioeconomic infrastructural facilities such as electricity, water, telephone etc. Utility mapping itself deals with the spatial inventory of these utilities and their representation in map form at an appropriate scale. It is necessary for efficient distribution and maintenance of the utilities.

In the paper by Sinha (2011), a geo-referenced electrical network map is overlaid on an area base map which is best in managing assets and their maintenance, but also being used for mapping the electrical consumers to its source of supply for energy audit applications. Moreover, by integrating electrical GIS with network analysis application, various analytical are possible for load flow analysis, short circuit analysis, efficiency calculations and load planning. This paper describes how GIS is being leveraged in power utilities for energy audit and network analysis and emerging as a powerful tool for load planning and management with the aim to improve the quality of electricity supply and related services (Adejoh, 2015). The study assesses the spatial relationship between power holding company of Nigeria (PHCN) assets and their customer's connectivity in the study area and makes decision on how to improve and manage electricity distribution. The result shows that the study area has only one transformer rated 500KVA with 4 upriser connected to numerous distribution lines serving 250 buildings with an average consumption rate of $2.1 \mathrm{KW}$ and total consumption of $525.6 \mathrm{KW}$ with an excess of $25.6 \mathrm{KW}$, indicating that the transformer is overloaded. It is evident from the finding that asset management, load shedding technique, can easily be managed with the use of geospatial technique.

The research of Kumar (2016) focuses on the application of emerging technologies like GIS (Geographic Information System) and GPS (Global Positioning System) which are capable of carrying out power system analysis like load flow analysis, load movement, electrical line (HT/LT) changes and electric asset management system using the ArcGIS 10.1 platform in Bhadohi city of Uttar Pradesh, India. High resolution remote sensing data is used to prepare various thematic layers i.e. settlement, transportation network map and other land base and performed survey of electrical asset data of Bhadohi, which is finally integrated into GIS platform. Number and types of electric poles, poles ID, distribution transformers (DTRs), the length of HT/LT lines etc. are collected during the field survey. The geographic location of each distribution transformer in the study area has been 
acquired using GPS and mapped in the hard copies of satellite data. It was that while there were 433 distribution transformers found in 2015 only 336 were recorded in 2011. (Dixit, 2008) The major objective of a utility is to supply the power demand with good quality of service, through proper planning of the system. This has led to development of methods which can be used to aid the decision-making process for selecting best alternative. GIS (Geographical Information System) and remote sensing technology-based electricity distribution system planning strategy is an approach to determine an optimum routing. Existing and proposed layouts has been drawn using GIS based software ARCVIEW 3.2a. It facilitates the attachment of data with the corresponding geographic. A comparison between load flow analysis of existing and proposed layouts of distribution system has been performed to find out the technical feasibility of the proposed routes. The information obtained from the power flow study is the magnitude and phase angle of the voltage at each bus and the real and reactive power flowing in each line. Optimum conductor has been selected for each feeder. Then for finding out the optimum layout among three, cost comparison is done, which will provide the most economically- viable layout. The developed system is tested on 57 buses, 56 branches, and 6 feeders of a sample substation of IIT Roorkee distribution system. The complete set of data required for the load flow analysis including the bus voltage, line currents, $\mathrm{kW}$ loads, power factor, meter reading, hourly data as well as spatial data required for GIS such as location of all the substations, buses and alignments of all $11 \mathrm{kV}$ and 440 volts feeders, rates of accessories used for the electricity distribution were collected in an extensive ground survey.

The application of GIS to electricity distribution has the capabilities for recording and managing electricity distribution system. Creation of a digital database and building of information system for Ashamu layout, Kosobo area, Oyo, Oyo East Local Government Area will help PHCN of Oyo branch to solve the problem of electricity distribution system planning and management. The analysis of the created database in the study area yields useful information as a decision support system to PHCN in solving the erratic power supply problem at Ashamu layout, Kosobo area, Oyo, Oyo East, Local Government Area.

\subsection{Materials and Methods}

The study area is Ashamu Layout Kosobo Oyo, Oyo East Local Government Area Oyo State, Nigeria. It lies between Latitudes $70^{\circ} 49^{\prime} 20^{\prime \prime} \mathrm{N}$ to $70^{\circ} 50^{\prime} 07^{\prime \prime} \mathrm{N}$ and Longitudes $30^{\circ} 56^{\prime} 10^{\prime \prime} \mathrm{E}$ to $30^{\circ} 56^{\prime} 51^{\prime \prime} \mathrm{E}$ having neighboring towns like Akinmorin and Awe. The layout is majorly residential; Ashamu layout has an approximate area of about $40 \mathrm{~km}^{2}$ with a population of about 25,750 as at 2006 census exercise. The area is mostly dominated by poultry farmers and fishery due to its proximity to river. It has a nearly flat terrain. Facilities such as pipe-borne water, good road network, hospitals, playground, town hall, schools and other basic amenities are all available. Majorly, the soil type in the area is loamy, which is one of the reasons for embracing farming in the area. 


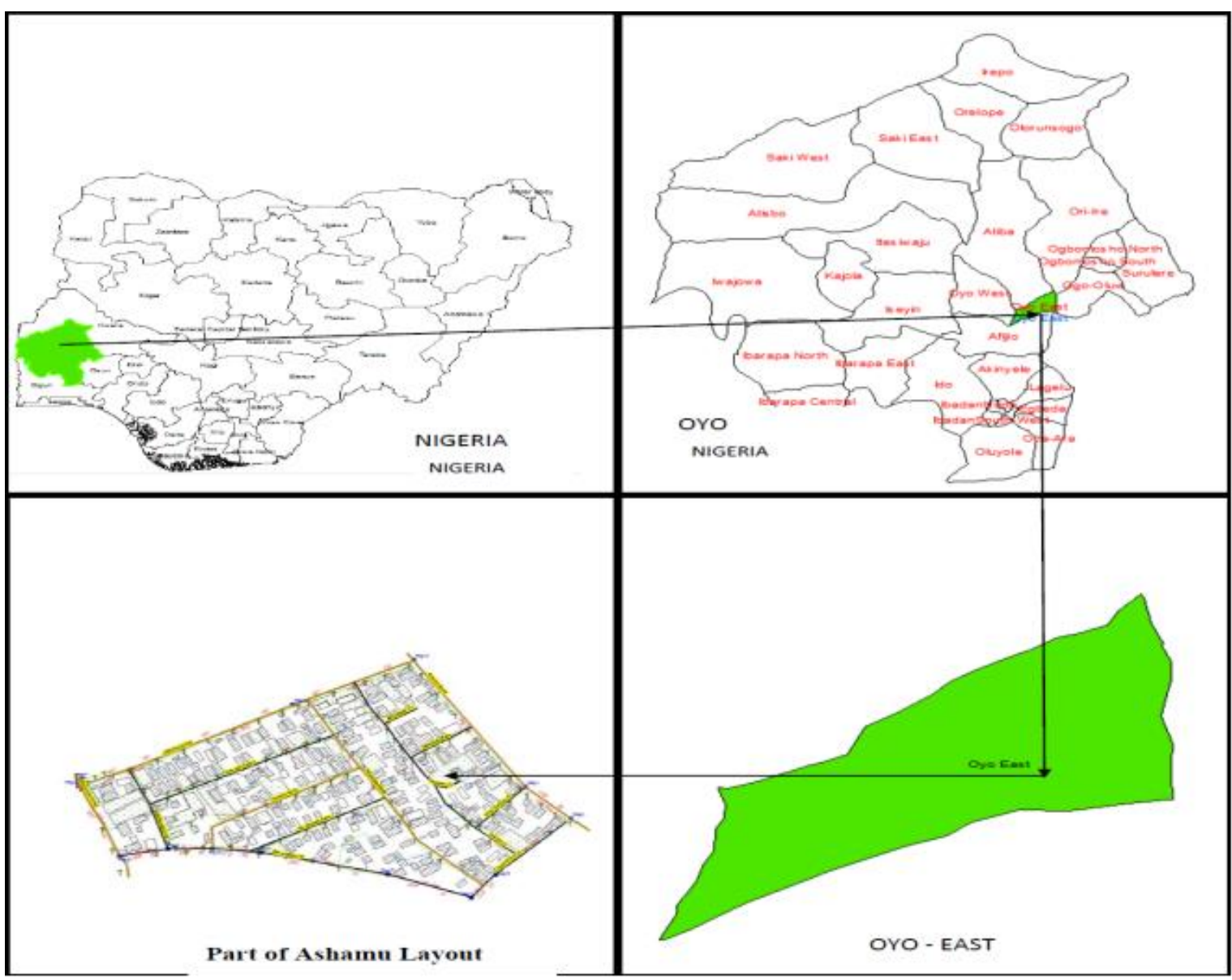

Figure 1: Map of the study area

\subsection{Database Design}

According to Igbokwe (2009), A database is an organized, integrated collection of non- redundant data stored so as to be capable of use be relevant applications with the data been accessed through some logical path. It is a collection of information organized into interrelated tables of data and specifications of data objects. Database is the hearth of GIS.

Database design phase consists of two phases, the design phase and the construction or implementation phase. The design phase consists of conceptual design, logical design and physical design. The construction phase consists of spatial database.

Realities were articulated based on geographic data within the study area with respect to electricity distribution facilities. In this case, reality includes the following geographic features: Catchment Areas, Streets, PHCN Transmission, 11kv Lines, power Transformer, and Distribution Transformer.

\subsubsection{Conceptual Design}

Conceptual design refers to the representation of the human conceptualization of the reality. When translating the reality of conceptual model, the articulated realities will be represented in a simplified manner and at the same time satisfied the information required by the users (Kufoniyi 1998). Therefore, vector data modeling was adopted. These realities were represented and displayed as lines, point or polygon, with their attributes defined by pair of plane coordinates (X, Y). A flow chart of the ER diagram is shown below 

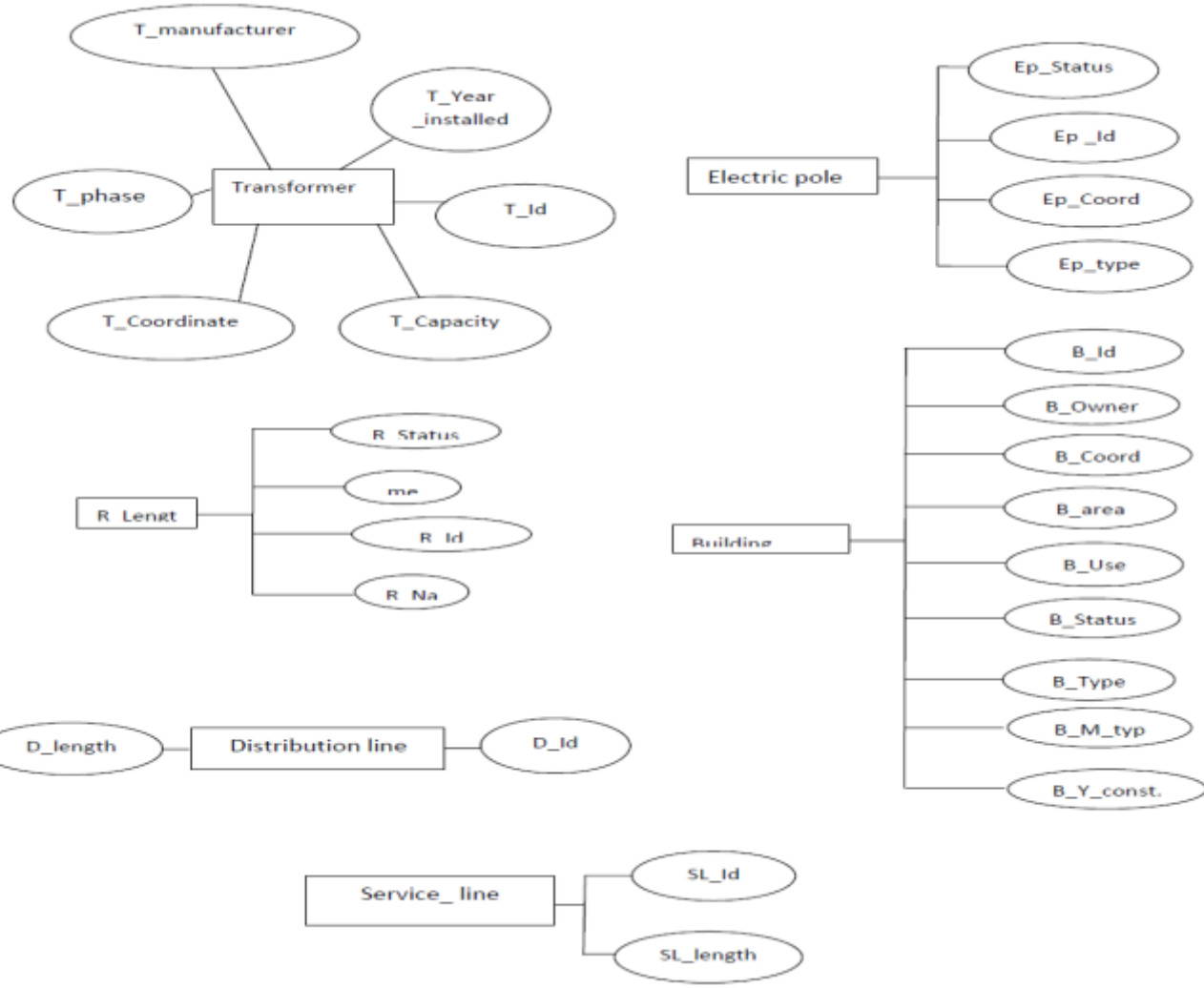

Figure 2: Entity-Relation Diagram (Kufoniyi, 1998)

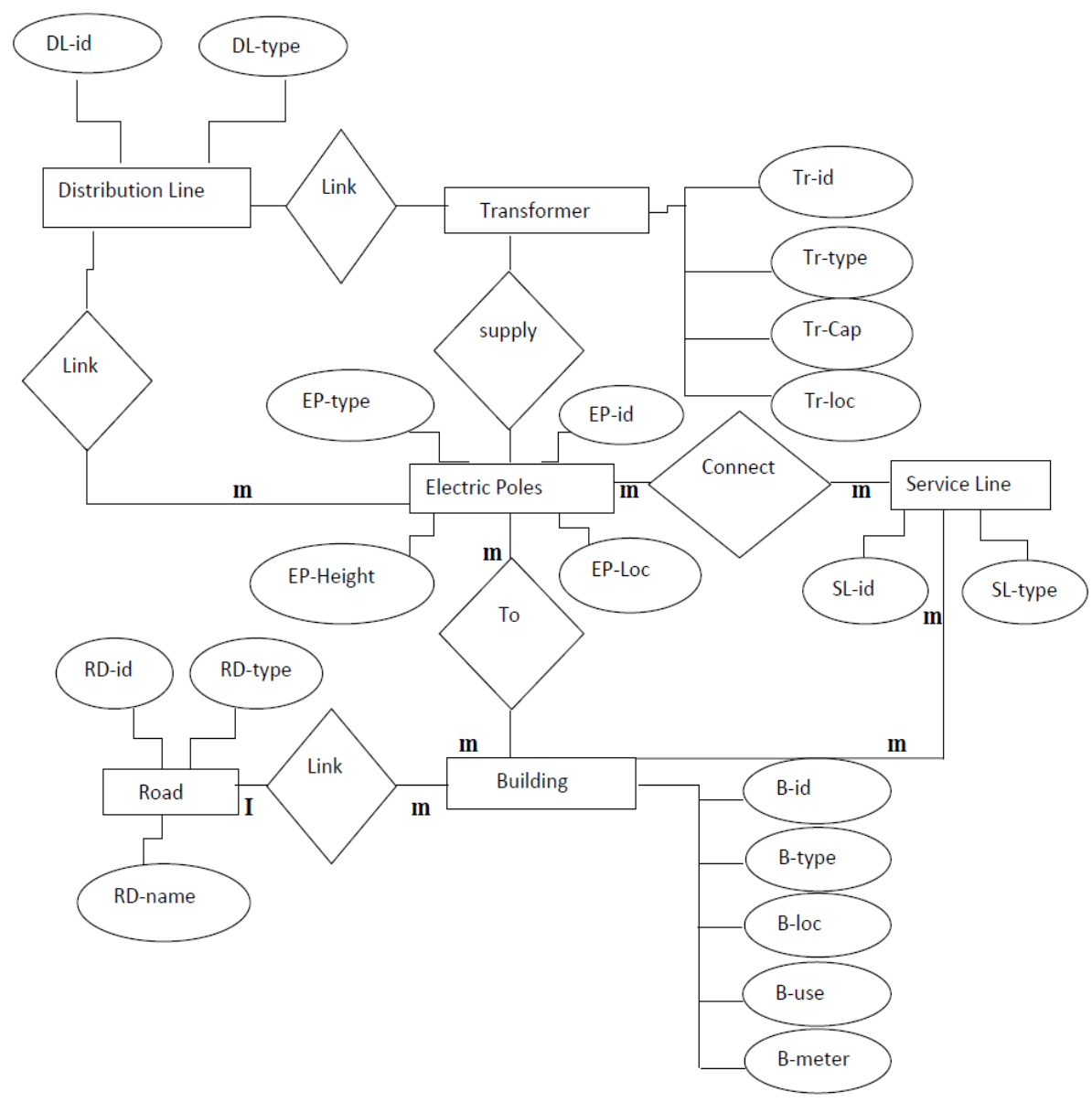

Figure 3: Entity-Relation Diagram (Kufoniyi, 1998) 


\subsubsection{Logical Design}

This refers to the translation of conceptual model into logical design to represent a data modal which can be acceptable by the computer that is the representation of data in a computer memory. In this stage, the data were structured to describe logically arrangement of data in the database. From the entity-relationship diagram, the following tables were designed.

Table 1: Attributes of Building

\begin{tabular}{|c|c|c|}
\hline S/No & Attribute Name & Description \\
\hline 1 & B_Id & Building Identifier \\
\hline 2 & B_Owner & Building Owner \\
\hline 3 & B_Use & Building Use \\
\hline 4 & B_Status & Building Status \\
\hline 5 & B_S_Name & Building Street Name \\
\hline 6 & DLINE_Num & Distribution Line Number \\
\hline 7 & M_Type & Meter Type \\
\hline 8 & Trasnformer & Transformer \\
\hline 9 & B_Area & Building Area \\
\hline
\end{tabular}

Table 2: Attributes of Electric Pole

\begin{tabular}{|c|c|c|}
\hline S/No & Attribute Name & Description \\
\hline 1 & Ep_Id & Electric Pole Identifier \\
\hline 2 & Ep_Type & Electric Pole Type \\
\hline 3 & Ep_Use & Electric Pole Use \\
\hline 4 & Ep_Status & Electric Pole Status \\
\hline
\end{tabular}

Table 3: Attributes of Transformer

\begin{tabular}{|c|c|c|}
\hline S/No & Attribute Name & Description \\
\hline 1 & T_Id & Transformer Identifier \\
\hline 2 & T_Capacity & Transformer Capacity \\
\hline 3 & T_Frequence & Transformer Frequency \\
\hline 4 & T_Year & Transformer Year \\
\hline 5 & T_Serial No & Transformer Serial No \\
\hline 6 & T_Y_Installation & Transformer Year Installation \\
\hline 7 & Easting & Easting \\
\hline 8 & Northing & Northing \\
\hline
\end{tabular}

Table 4: Attributes of Road

\begin{tabular}{|c|c|c|}
\hline S/No & Attribute Name & Description \\
\hline 1 & R_Id & Road Identifier \\
\hline 2 & R_Name & Road Name \\
\hline 3 & R_Status & Road Status \\
\hline 4 & R_Length & Road Length \\
\hline
\end{tabular}

\subsection{Data Acquisition}

There are two ways of acquiring data for any project; these are primary data acquisition and secondary data acquisition. The primary data acquisition includes both spatial and attributes data. The data set of the spatial data was acquired through the use of Sokkia 630R Total Station and the attribute 
data was acquired through social survey that involved asking questions from the residents anything concerning the utility in the area. The secondary data acquisition involved the collection of the coordinates of the control pillar used for the project and also information about electric facilities obtained from Power Holding Company of Nigeria (PHCN).

\subsection{Geometric Data Acquisition}

South NTS Total Station was used in acquiring geometric data. The instrument was set up on FSS2/GPS02 and all the necessary temporary adjustment was carried out. The instrument was powered on and the job name created. The coordinate of the controls were then inputted into the instrument. The coordinates of the station was set and orientation was performed to the back station. Turning clockwise to the fore station, the reflector was bisected and ALL button pressed to make measurement. After the REC button was pressed the measurement was recorded. The process was repeated for each station set up and through this, all needed features such as roads, electric poles, transformers were observed.

\subsection{Attribute Data Acquisition}

The attribute data is the observed fact about entities and it is one of the basic components of a spatial database. It was acquired through social survey that is asking questions on the electricity distribution and mapping network of Ashamu Layout, kosobo, Oyo East Local Government Area of Oyo State. The attribute data collected includes name of buildings, name of the streets, meter types, meter number, type of pole, height and size of the poles were also obtained from the Power Holding company of Nigeria (PHCN). The diagram below shows the ER adopted for the project.

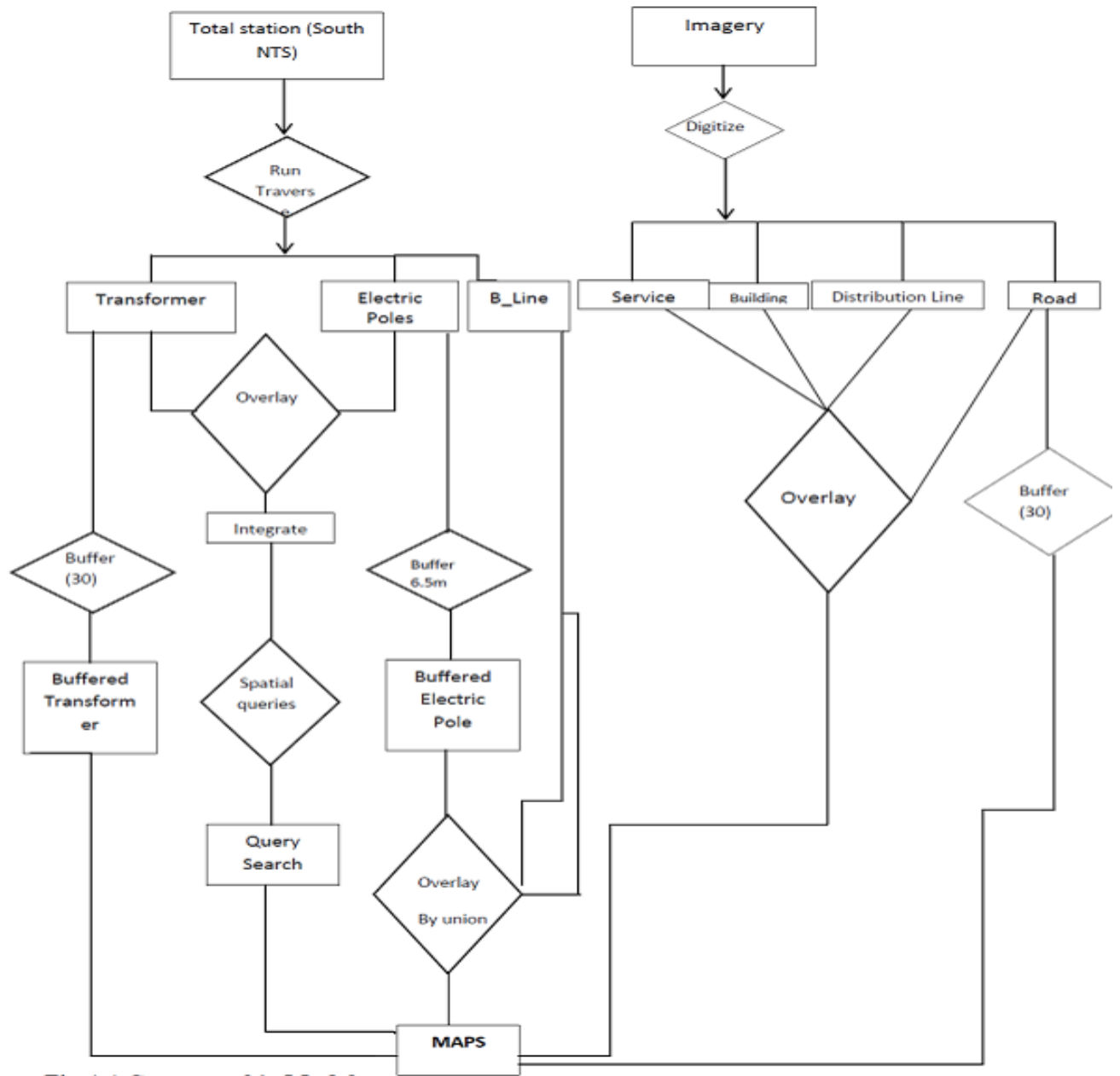

Figure 4: Entity-Relation Diagram Adopted for the Project 


\subsection{Results and Discussion}

\subsection{Spatial Query}

Spatial query in a mathematical analysis of the database created for the study area in order to analyze and manipulate the data in solving problems and also indentifying the spatial distribution of data in the database.

\subsubsection{Single Criterion Analysis}

\section{Syntax is: SELECT *FROM ELECT_POLE WHERE "POLE_TYPE"="WOODEN"}

The Spatial query command to determine the location of wooden electric poles with the study area in order to know the distribution.
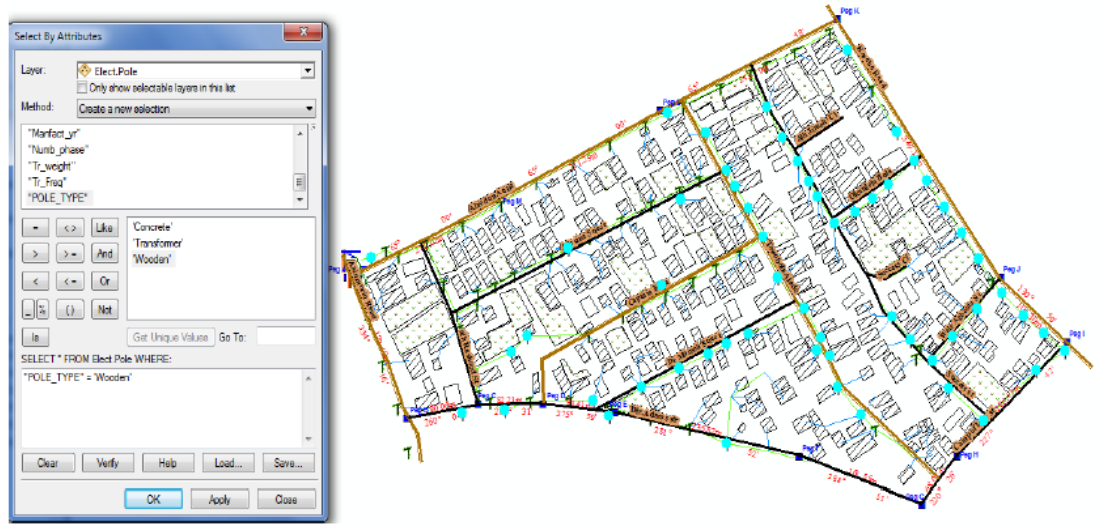

Figure 5: The location map to display wooden electric poles

\subsubsection{Single Criterion Query}

\section{Syntax is: SELECT *FROM BUILDING WHERE “MET_OF_BILL”="DIRECT BILLING”}

The query below shows and highlights the buildings within the study area that have a direct billing system.
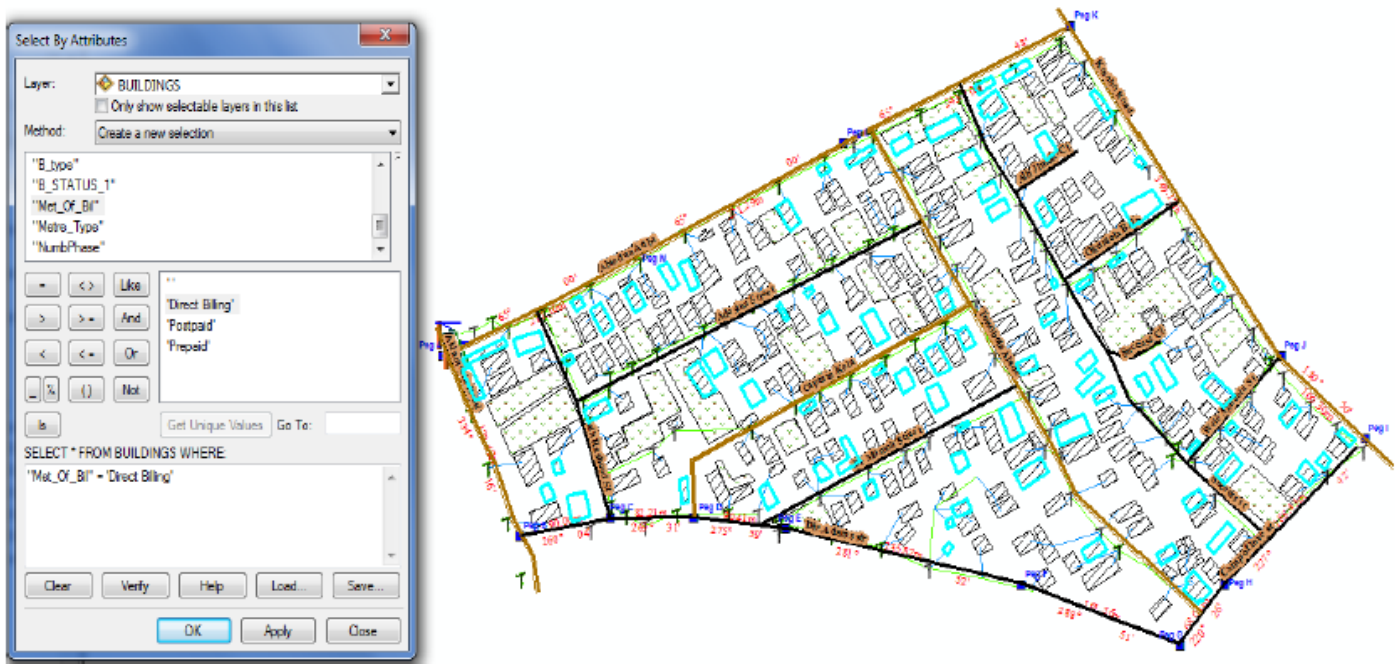

Figure 6: The Operation Map to Display Buildings Using Direct Billing Method 


\subsubsection{Multiple Criteria Analysis}

Syntax is: SELECT* FROM BUILDINGS WHERE "B_STATUS_1"="COMPLETED"AND "METER_TYPE"="ANALOGUE"

The query below illustrates the buildings that are making use of analogue meter
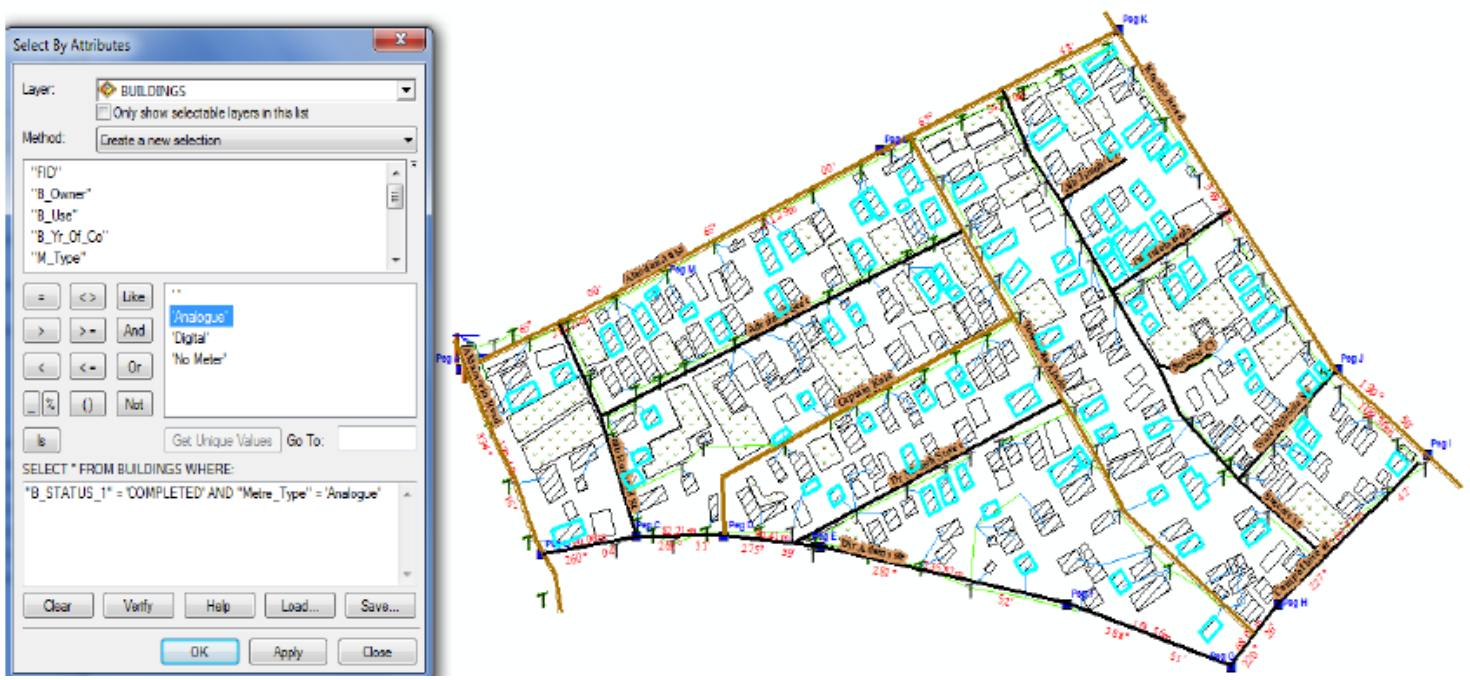

Figure 7: The Operation Map to Display Completed Buildings Using Analogue Meters

\subsection{Buffering Analyses}

Criteria for the buffer analyses are as follows:

(i) According to the IBEDC, Oyo Area Unit stated that the electric pole should be erected at least $6 \mathrm{~m}$ distance to building.

(ii) Building should be at least $30 \mathrm{~m}$ away from the transformer

Figure 8 shows a buffer analysis showing the buildings that contravene the laid down rules of $30 \mathrm{~m}$ setback. Figure 9 show a buffer analysis of buildings that are within the 6.5 meter the restriction

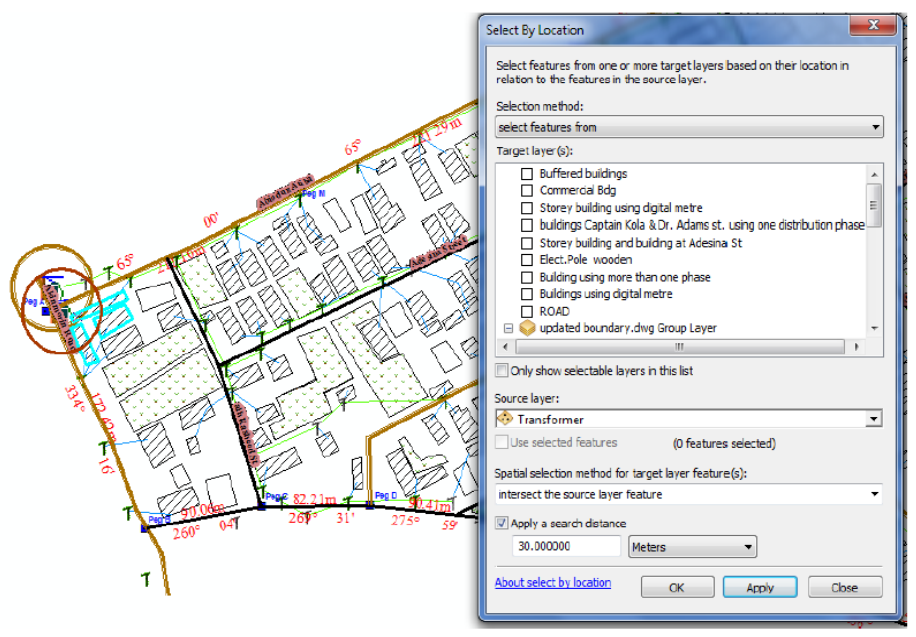

Figure 8: Map to Display Buildings That Violated 30m Setback from Transformer 


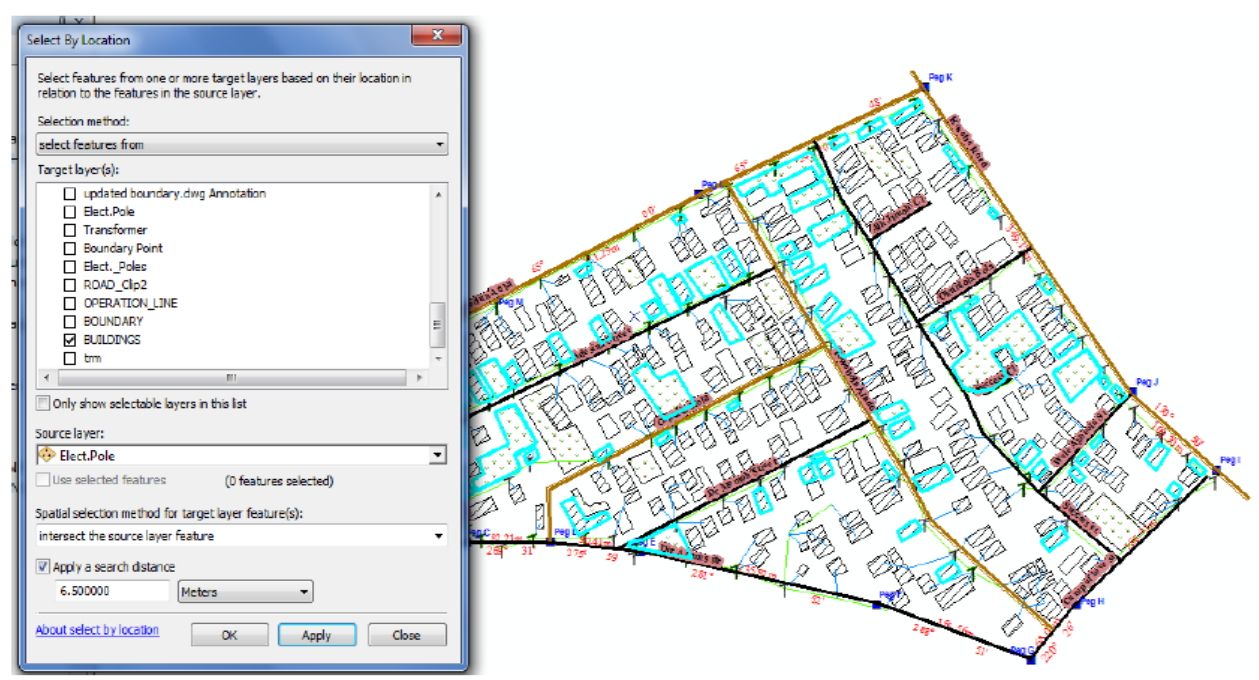

Figure 9: Operation for Buffer of electric poles at 6.5meters

TABLE 5. ANALYSIS DESCRIPTION FOR THE QUERY AND BUFFERING

\begin{tabular}{|c|c|c|c|c|}
\hline \multirow{2}{*}{ S/N } & \multirow{2}{*}{ Entities } & \multicolumn{2}{|c|}{ Building } & \multirow{2}{*}{ Sum } \\
\cline { 3 - 4 } & & Conforms & Not conform & \\
\hline 1 & Buffered Violated building & 264 & 3 & 267 \\
\hline 2 & Building using direct billing & 80 & 187 & 267 \\
\hline 3 & Completed buildings using analogue & 85 & 182 & \multirow{2}{*}{267} \\
\hline 4 & $\begin{array}{c}\text { No. of buildings affected by buffered } \\
\text { electric poles at 6.5m }\end{array}$ & 42 & 225 & 169 \\
\hline 5 & Wooden poles & 57 & 112 & \\
\hline 6 & Total number & Building $=267$ & Electric poles $=169$ & \\
\hline
\end{tabular}

The table above gives a numerical value of the buildings that conform and do not conform with the laid down rules for electrification within the study area and also the location of electric poles.

\subsection{Discussion of Results}

Having employed various methods, there was a clear indication that using the single and multiple criteria, three spatial queries and one buffering were performed, the project area was 25.91 Hectares.

In Figure 5, it was discovered that there are 57 poles were wooden out of the total sum of 169 revealing that the rest 112 were concrete poles. With recent findings it has been discovered that the wooden pole has been in use for about 30years ago. This query was employed to estimate the total number of wooden poles to be replaced with concrete poles to avoid breakage. It has been established that concrete poles are stronger, durable, better and long lasting compared to wooden.

In Figure 6, 80 buildings were shown to be using direct billing in the area out of the total sum of 269, this will considerably help and assist the electricity agency (PHCN) to determine the numbers of houses which are not using meters. This will help to curb the unlawful act of connecting to electricity without the permission of agency (PHCN), it could also be used to calculate houses in need of meters.

From Figure 7, it was discovered that 85 completed buildings were using analogue meters. In this case, it will help the PHCN to estimate the total number of digital meters needed in the area if need arises. From Figure 8, the buffering made was to determine the buildings that did not conform with 
the laid down set-back by power holding company of Nigeria which is 30 metres for the closeness to the transformer and the 6.5metres setback of buildings to pole the result showed 3 buildings out of 267 buildings that did not conform with the standard set back of the building from the transformer.

These results demonstrated some of the capabilities of GIS in handing and managing electricity distribution spatial data. With GIS, one can manipulate and carry out tasks that are vital in management of electricity for proper and efficient results. When new facilities are installed, the GIS database and graphical (map) components can be updated easily to accommodate the new features. So, map revision and digital mapping become easy in GIS environment.

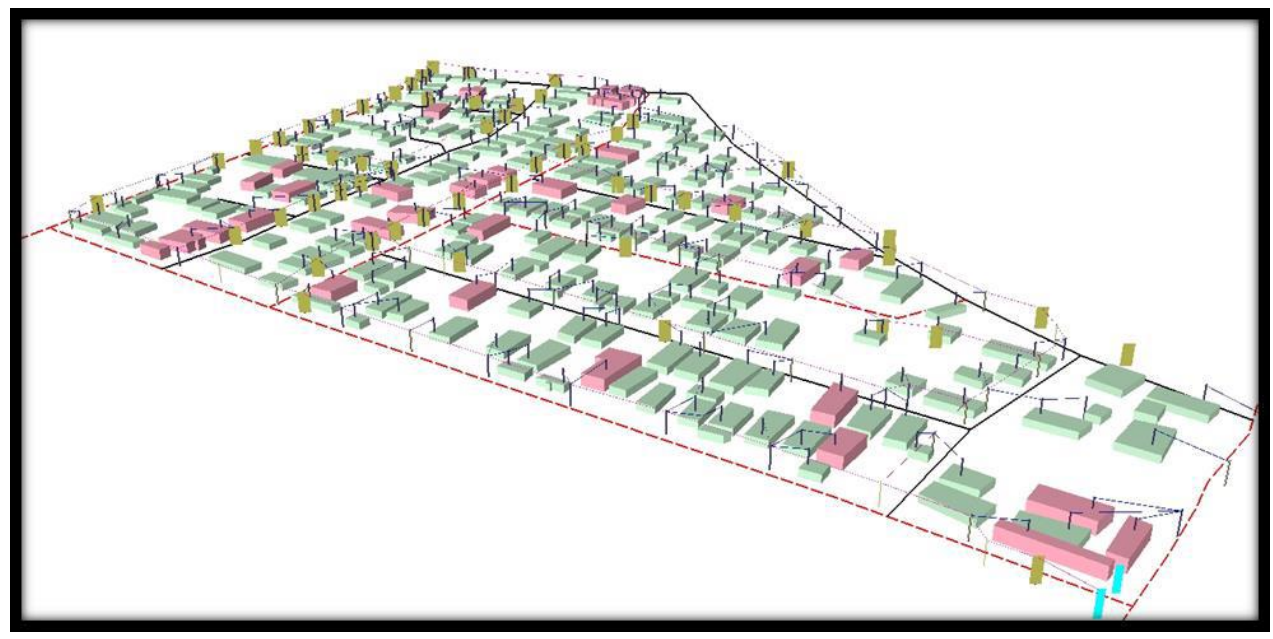

Figure 9: 3D view of the project area

\subsection{Conclusion and Recommendation}

Electricity is one of the most vital needs of our everyday lives whose generation, transmission and distribution need to be properly monitored and maintained. Digital system provides timely, accurate, and easier way of acquiring information, which is very important in taken prompt and accurate decisions necessary in the economic development of our country. More efforts must be made to bring in such refined and scientific approaches. GIS would prove to be cutting edge technology in decision making for power safeguarding.

From this study undertaken, it is found that a complete information system for the Power Holding Company of Nigeria (PHCN), Oyo can be used in many ways to improve the planning, maintenance and management of electricity distribution system. It can be used to achieve following points efficiently:

i. This study has proved that updated complete information is required for identification of the consumers within the study area.

ii. A Database Management System integrated with Geographical Information System can help find solutions to identification of each and every consumer and their locations with their connectivity in the study area.

iii. This GIS based system helps in not only identification of each and every plot location but also provides complete information about the consumer.

The following recommendations are suggested;

i. PHCN of Oyo East branch should be keeping update complete information for identification of the electricity consumer within Oyo East.

ii. PHCN of Oyo East need to employ Geo-informaticians that will be helping the organization to acquired, processed, managed and present spatial data about electricity facilities. 
iii. The GIS based system will help the Power Holding Company of Nigeria (PHCN), Oyo East branch to find the shortest route from the office to problem location.

iv. Electrical fault management is done when the transformer under fault is known. The distribution transformer under fault is selected and linked to the database with the help of GIS. From the database the affected areas were found and displayed on the map. This will help PHCN in the planning of maintenance.

v. PHCN should introduce an information system with real-time metering to aid in day-to-day monitoring, operation and maintenance in order to improve the efficiency of the system resulting in customer satisfaction.

\section{References}

Adejoh (2015) Application of GIS in Electrical distribution network system; European international journal of science and technology vol. 4 no. 8

Adekunle, A.A. (1995) "Utility Mapping Using GIS Technique: A Case Study of University of Lagos", Unpublished B. Sc. Project Submitted to the Department of Geography and Planning, University of Lagos.

Ajibade S.A (2002) The use of GIS in environmental protection and monitoring (A case study of Utility Management). A paper presented at the NIS 37th AGM and Conference/Workshop at Owerri, Imo State.

Dixit (2008) Optimum Routing of Distribution System Network Using GIS and Remote Sensing Technology. Fifteenth National Power Systems Conference (NPSC), IIT Bombay, December 2008

Asoegwu and Ndukwu (2002) Electricity Generation, Transmission and Distribution in Nigeria: The Indispensable Role of Geoinformatics Proceedings of the Technical Session of the 37th Annual General Conference and Meeting of NIS at Owerri, Imo State, Nigeria.

ESRI (2010). ESRI Experience in the Use of GIS for Census Mapping Applications. United Nations Statistical Division Workshop on Census Mapping with GIS

Igbokwe, J. I. and Emengini, E. J. (2009). GIS in Management of Electricity Distribution Network: A case study of Onitsha-North L.G.A., Anambra state, Nigeria. Geospatial World. Available online at: https://www.geospatialworld.net/article/gis-in-management-of-electricity-distribution-network-acase-study-of-onitsha-north-l-g-a-anambra-state-nigeria/

Kufoniyi, O. (1998) Database Design and Creation, in C.U. Azeigbo (ED), Principles and Application of Geographic Information System, Lagos, Panef Press, Pg. 1-5

Kumar (2016) GIS IN Electrical Asset Mapping: The case of Bhadohi, India European Journal of Geography Volume 7, Number 4:19 - 33, December 2016

Sinha (2011) Enabling GIS in Distribution Utility for Energy Audit and Load flow analysis; 12th ESRI India User Conference 2011

This Day, (2002), “Obasanjo Gives NEPA Fresh Mandate: Orders 10,000mw by 2005”, Leaders and Company Ltd, Lagos, 24 January, pp.1.

\section{Cite this article as:}

Oseni A. E. and Durowoju A. S., 2020. Application of GIS in Electricity Distribution: A Case Study of part of Ashamu Layout Kosobo, Oyo East Local Government Area, Oyo State Nigeria. Nigerian Journal of Environmental Sciences and Technology, 4(2), pp. 370-381. https://doi.org/10.36263/nijest.2020.02.0106 